\title{
Correction to: Inducement grants, hiring announcements, and adverse selection for new CEOs
}

\author{
Brian Cadman ${ }^{1}$ (D) $\cdot$ Richard Carrizosa $^{2} \cdot$ Xiaoxia Peng $^{1}$
}

Accepted: 24 December 2020/ Published online: 19 January 2021

(C) The Author(s) 2021

Correction to: Review of Accounting Studies (2020) 25(1):279-312 https://doi.org/10.1007/s11142-019-09517-9

The article "Inducement grants, hiring announcements, and adverse selection for new CEOs", written by Brian Cadman, Richard Carrizosa and Xiaoxia Peng, was originally published Online First without Open Access. After publication in volume 25, issue 1, page 279-312 the author decided to opt for Open Choice and to make the article an Open Access publication.

Therefore, the copyright of the article has been changed to (C) The Author(s) 2020 and the article is forthwith distributed under the terms of the Creative Commons Attribution 4.0 International License, which permits use, sharing, adaptation, distribution and reproduction in any medium or format, as long as you give appropriate credit to the original author(s) and the source, provide a link to the Creative Commons licence, and indicate if changes were made. The images or other third party material in this article are included in the article's Creative Commons licence, unless indicated otherwise in a credit line to the material. If material is not included in the article's Creative Commons licence and your intended use is not permitted by statutory regulation or exceeds the permitted

The online version of the original article can be found at https://doi.org/10.1007/s11142-019-09517-9

Brian Cadman

brian.cadman@eccles.utah.edu

Richard Carrizosa

rdcarrizosa@utep.edu

Xiaoxia Peng

xiaoxia.peng@eccles.utah.edu

1 David Eccles School of Business, University of Utah, 1655 E Campus Center Dr., Salt Lake City, UT 84112, USA

2 College of Business Administration, University of Texas at El Paso, 500 W. University Ave., El Paso, TX 79902, USA 
use, you will need to obtain permission directly from the copyright holder. To view a copy of this licence, visit http://creativecommons.org/licenses/by/4.0/.

Open Access This article is licensed under a Creative Commons Attribution 4.0 International License, which permits use, sharing, adaptation, distribution and reproduction in any medium or format, as long as you give appropriate credit to the original author(s) and the source, provide a link to the Creative Commons licence, and indicate if changes were made. The images or other third party material in this article are included in the article's Creative Commons licence, unless indicated otherwise in a credit line to the material. If material is not included in the article's Creative Commons licence and your intended use is not permitted by statutory regulation or exceeds the permitted use, you will need to obtain permission directly from the copyright holder. To view a copy of this licence, visit http://creativecommons.org/licenses/by/4.0/.

Publisher's note Springer Nature remains neutral with regard to jurisdictional claims in published maps and institutional affiliations. 